\title{
PENAMPILAN REPRODUKSI TERNAK SAPI POTONG YANG DI INSEMINASI BUATAN DI KECAMATAN TOMBATU UTARA DAN KECAMATAN RATAHAN
}

\author{
Ariny Irma Sawel, Agustinus, Lomboan*, Jantje Paath, Jouke Manopo \\ Fakultas Peternakan Universitas Sam Ratulangi Manado
}

\begin{abstract}
ABSTRACK
Tujuan penelitian ini untuk mengetahui penampilan reproduksi ternak sapi potong yang diinseminasi buatan di Kecamatan Tombatu Utara dan Kecamatan Ratahan di Kabupaten Minahasa Tenggara. Data hasil penelitian dianalisis secara statistik deskriptif yaitu dengan tabulasi data, menghitung nilai rata-rata, standar deviasi dan koefisien keragaman. Hasil penelitian diperoleh bahwa penampilan reproduksi ternak sapi potong yang diinseminasi buatan di Kecamatan Tombatu Utara dan Kecamatan Ratahan adalah service per conception 1,25-1,30, conception rate $70-75 \%$, calving interval 366,4-377,55 dan lama kebuntingan 279,25-281,1 hari. Kesimpulannya adalah penampilan reproduksi ternak sapi potong yang diinseminasi buatan di Kecamatan Tombatu Utara dan Kecamatan Ratahan sudah tergolong baik.
\end{abstract}

Kata kunci: Reproduksi, Sapi Potong, Inseminasi Buatan

*korespondensi (correspondingAuthor) Email agustinuslomboan@yahoo.co.id
ABSTRACT

REPRODUCTIVE PERFORMANCE BEEF CATTLE OF ARTIFICIAL INSEMINATION IN THE DISTRICT OF NORTH TOMBATU AND SUB DISTRICT OF RATAHAN. The porpose of this study to know appearance of reproduction beef cattle artificial insemination in the northern Tombatu District and the Sub District of Ratahan in the Southeast Minahasa Regency. Research the everage valve standard deviation and coefficient of diversity. Based on research results that service preconception 1.25-1.30, conception rate $70-75 \%$, calving interval 366.4-377.55 and length of pregnancy 279.25-281.1 day. It can be colcluded that the reproductive performance of artificial insemination beef cattle in North Tombatu and Ratahan Districts already quite good.

Keywords: Reproduction, beef cattle, artificial insemination

\section{PENDAHULUAN}

Inseminasi buatan (IB) adalah penempatan semen pada saluran reproduksi yang dibantu oleh tenaga inseminator. Semen yang ditempatkan dapat berupa semen beku yang sudah dicairkan atau semen segar. Inseminasi buatan ini telah 
dilakukan sejak dua abad yang lalu. Pengembangan peternakan di Indonesia bertujuan untuk mendapatkan pangan yang bergizi dan berdaya saing tinggi. Ternak sapi sebagai komuditi penghasil daging dan susu dapat diharapkan menjadi penopang dalam upaya pembangunan peternakan. Salah satu kebijakan pemerintah dalam peternakan sumber protein hewani asal ternak.Khusus untuk ternak sapi pada umumnya daging dihasilkan oleh sapi potong seperti sapi Bali, sapi Madura, dan sapi Peranakan Ongole (PO), seperti sapisapi import.

Masalah ketersediaan daging terutama daging sapi potong, belum cukup dan belum dapat memenuhi permintaan masyarakat terutama pada hari-hari besar. Ada beberapa faktor sehingga ketersediaan daging sapi belum maksimal diantaranya adalah rendahnya masalah reproduktifitas ternak sapi potong di Indonesia, rendahnya tingkat kelahiran, lambat beranak, jarak beranak panjang, tingkat kematian pedet tinggi dan perbaikkan genetik lambat. Tinggi rendahnya efisiensi reproduksi ternak dipenggaruhi jumlah layanan inseminasi buatan, jumlah ternak yang bunting saat pertama kali diinseminasi buatan dan lama kebuntingan (Hardooprantjoto, 1995). Penelitian ini dilaksanakan untuk mengetahui penampilan reproduksi ternak sapi potong yang diinseminasi buatan di Kecamatan
Tombatu Utara dan Kecamatan Ratahan di Kabupaten Minahasa Tenggara.

\section{MATERI DAN METODE PENELITIAN}

\section{Lokasi dan Waktu penelitian}

Penelitian ini telah dilaksanakan sejak tanggal 1 Agustus sampai 1 Oktober tahun 2018, bertempat di dua Kecamatan yaitu Kecamatan Tombatu Utara dan Kecamatan Ratahan dimana terdapat jumlah inseminasi ternak terbanyak.

\section{Materi Penelitian}

Materi yang digunakan dalam penelitian ini adalah sapi milik peternak yang diambil secara sampel dibeberapa desa di Kecamatan Tombatu Utara dan Kecamatan Ratahan.

\section{Populasi dan Sampel}

1) Populasi

Populasi dalam penelitian ini adalah seluruh ternak sapi yang ada di Kecamatan Tombatu Utara dan Kecamatan Ratahan.

\section{Metode Penelitian}

Metode penelitian yang dilakukan dalam penelitian ini adalah metode survey dengan menggunakan data primer dan sekunder, Data primer diperoleh pada daftar pertanyaanatau kusioner yang telah disiapkan) dengan sejumlah peternak dengan memiliki sapi potong jumlah 
pemilikan 4 ekor sapi, ada yang sapi penjantan dan juga sapi betina ada pedet dan sapi yang belum diinseminasi buatan. Sedangkan data sekunder diperoleh dari berbagai instansi terkait dengan penelitian ini seperti dinas peternakan, monografi kecamatan, kantor statistic dan lainlain.Pemilihan sampel desa ditentukan secara sengaja (purposive) dengan pertimbangan tertentu (Sugiyono, 2010) yaitu desa yang memiliki jumlah ternak yang diinseminasi terbanyak. Pemilihan responden peternak sapi potong menggunkan random sampling karena pengambilan sampel anggota populasi dilakukan secara acak tanpa memperhatikan strata yang ada dalam populasi (Sugiyono, 2010) mengambil peternak dari masing-masing desa terpilih sehingga mendapatkan 20 responden,yakni 10 responden di Kecamatan Tombatu Utara dan 10 responden di Kecamatan Ratahan. Dengan jumlah ternak sapi yang diinseminasi yakni 20 ekor di Tombatu Utara dan 20 ekor sapi di Kecamatan Ratahan.

\section{Variabel Yang di Teliti}

Variable yang diamati pada ternak sapi potong yang diinseminasi buatan di Kecamatan Tombatu Utara dan kecamatan Ratahan di Kabupaten Minahasa Tenggara.

\section{Service per conception}

Banyaknya perkawinan atau inseminasi buatan yang dilakukan hingga ternak menjadi bunting.Perhitungan nilai S/C menurut Hafez (2000) yaitu sbb:

$$
s c=\frac{\text { jumlah layanan } \mathrm{x} 100 \%}{\text { jumlah betina yang bunting }}
$$

\section{Conception Rate}

Conception rate adalah jumlah induk yang positif bunting dibagi jumlah ternak yang dikawinkan dikali 100\%, perhitungan nilai CR menurut Jaenudin dan Hafez (1987) yaitu mengunakan rumus sebagai berikut :

$$
c r=\frac{\text { jumlah betina bunting } \times 100 \%}{\text { jumlah akaseptor }}
$$

\section{Calving interval}

Perhitungan nilail CI menurut Ball dan Peters (2004)

Calving intervsl $($ bulan $)=$ kelahiran ke 1 kelahiran ke (i-1)

Clving interval (hari)= periode kebuntingan open days

\section{Lama Kebuntingan}

Lama kebuntingan dimulai dengan pembuahan dan berakhir dengan kelahiran pedet yang hidup (Toelihere , 1995)

\section{Analisis Data}

Data diolah secara deskriptif dan disajikan dalam bentuk tabel, mengunakan uji banding t-test. 


\section{HASIL DAN PEMBAHASAN}

\section{Service Per Conception}

Hasil penelitian yang didapat yaitu service perconception yang ada di Kecamatan Tombatu Utara dan Kecamatan Ratahan tidak berbeda nyata $(\mathrm{P}<0,05)$, seperti terilihat pada Tabel 1 , jadi service perconception yang ada di dua Kecamatan tersebut sudah baik, Service preconception atau jumlah layanan yang ada dilokasi penelitian di Kecamatan Tombatu Utara yaitu 1,3. Angka ini menunjukan bahwa dari 20 ekor ternak sapi dilakukan jumlah layanan IB sebanyak 26 kali untuk memperoleh kebuntingan dan di Kecamatan Ratahan 1,25 untuk memperoleh kebuntingan dibutuhkan 25 kali layanan IB. Ini menunjukan bahwa nilai service perconcepotion yang ada di lokasi penenlitian lebih baik dibandingkan dengan hasil penelitian yang didapat oleh Winarti dan Supriyadi (2010) di Yogyakarta yaitu service perconception 2,68 kali. Hasil penelitian yang dilakukan lebih baik dari penelitian yang dilakukan oleh Kasehung et al. (2016) di Kabupaten Minahasa yaitu service perconception 1,44 kali. Hasil Penelitian ini menunjukan bahwa semakin rendah service perconception semakin tinggi kesuburan ternak tersebut, ini berarti bahwa service perconception ternak sapi potong di Kecamatan Tombatu Utara dan Kecamatan Ratahan sudah tergolong baik.Service preconception dikatakan efisien apabila dilakukan cukup satu kali layanan inseminasi sampai memperoleh satu kebuntingan.

\section{Conception Rate}

Hasil penelitian conception rate atau sapi yang bunting pada saat pertama kali inseminasi buatan dapat dilihat pada Tabel 1. Conception rate di Kecamatan Tombatu Utara sebesar 70\%, ini berarti dari 20 ekor sapi yang diinseminasi buatan 16 ekor sapi mengalami kebuntingan,

Tabel 1. Rata-Rata Service Perconception, Conception Rate, Calving Interval dan Lama Kebuntingan Ternak Sapi Potong

\begin{tabular}{lcccc}
\hline \multicolumn{1}{c}{ Variabel } & Tombatu Utara & Ratahan & T Hitung & T Tabel \\
\hline Service Perconception & 1,3 & 1,25 & $1^{\mathrm{ns}}$ & 0,05 \\
Conception Rate (\%) & 75 & 70 & & \\
Calving Interval (hari) & 377,55 & 366,4 & $21,44^{* *}$ & 0,01 \\
Lama Kebuntingan (hari) & 280,1 & 279,25 & $44,73^{* *}$ & 0,01 \\
\hline
\end{tabular}

Sumber : Hasil Olahan Data Primer

** berbeda sangat nyata $(\mathrm{PO}>0.01)$ 
sedangkan conception rate di Kecamatan Ratahan sebesar $75 \%$ dari 20 ekor sapi yang diinseminaasi buatan, ini berarti 15 ekor sapi mengalami kebuntingan. Dan hasil yang didapat atau presentase sudah tergolong baik karena layanan inseminasi buatan dilakukan tidak lebih dari 2 kali. Baiknya conception rate di dua Kecamatan tersebut itu karena peternak memperhatikan makanan atau pakan dari ternak tersebut karena pemberian pakan yang baik sangat mendukung keberhasilan inseminasi buatan (Montiel dan Ahuja, 2005).

\section{Calving Interval / Jarak Beranak}

Calving interval (CI) adalah jangka waktu yang dihitung dari tanggal beranak seekor sapi sampai beranak kembali, atau jarak beranak dari anak satu keanak lainnya. Jarak beranak sapi potong yang ada di Kecamatan Tombatu Utara yaitu 377,55 hari, dan di Kecamatan Ratahan 366,4 hari hasil yang didapat lebih tinggi dari hasil penelitian Hadi dan Ilham (2004) yaitu memiliki CI 363 hari yaitu 9 bulan bunting dan 3 bulan menyusui demikian halnya dengan Ball dan Peters (2004) bahwa efisiensi reproduksi dikatakan baik apabila seekor induk dapat menghasilkan 1 anak pedet setiap tahun. Hal ini didukung oleh pendapat Rhodes et al. (2003) bahwa estrus pasca partus merupakan hal yang penting pada sapi untuk dapat melahirkan setiap tahun satu ekor anak sapi dengan jarak kelahiran 365 hari. Jarak beranak di lokasi penelitian berbeda sangat nyata yaitu $\mathrm{t}$ hitung 21,44 lebih besar dengan $\mathrm{t}$ tabel 2,59 dapat dilihat pada Tabel 1 .

\section{Lama Kebuntingan}

Hasil penelitian lama kebuntingan sapi di Kecamatan Tombatu Utara 280,1 hari dan di Kecamatan Ratahan 279,25 hari. Berdasarkan uji test hasilnya sangat berbeda nyata $(\mathrm{PO}>0.01)$. Apabila sapi betina dikawinkan pada umur 2 tahun dan terjadi kebuntingan pada umur 3 tahun maka telah mempunyai ketururnan anak (Saladin, 1993). Devandra et al. (1973) mengemukan bahwa rata-rata lama kebuntingan pada ternak sapi bali adalah 287,07 hari, sedangkan menurut penelitian Prasojo et al. (2010) adalah berkisar antara 278,7 hari. Sedangkan untuk ternak jenis Peranakan Ongole, Wibowo et al. (2014) menyatakan bahwa rata-rata lama kebuntingan adalah 270-290 hari.

\section{KESIMPULAN}

penampilan reproduksi ternak sapi potong yang diinseminasi buatan di Kecamatan Tombatu Utara dan Kecamatan Ratahan sudah tergolong baik 


\section{DAFTAR PUSTAKA}

Ball, P. J. H and A.R. Peters. 2004. Reproduction Incattle. Thrid Edition Blackwell Publishing Vivtoria. Australia. De Vries, A. 2006. Determinants Off days open in dairy cattle. Department of Animal Sciences University of Florida. Gainesville 32611. USA.

Devandra, C.T., K.C. Lee, Pathmasingam. 1973. The productivity of Bali cattle in Malaysia. J Agric 49: 183197.

Hadi, P.U dan N. Ilham. 2002. Problem dan prospek pengembangan usaha pembibitan sapi potong di Indonesia. Jurnal Litbang Pertanian. 21 (4): 148-147.

Hafez, E.S.E., 2000. Reproduction In Farm Animals. $7_{\text {th }}$ Edition Lippincott Wiliams \& Wilkins, Maryland. USA.

Jaenudeen, M. R. dan E. S. E Hafez 1987. Gestation, Prenatal Physiology and Parturition. In Reproduction in Farm Animals. $5^{\text {th }}$ Ed. E.S .E Hhaves (Ed) Lea and Febiger. Philadelphia.

Kasehung, J., U. Paputungan, S. Adiani, dan J. Paath. 2016. Performans reproduksi induk sapi lokal peranakan ongole yang dikawinkan dengan teknik inseminasi buatan di Kecamatan Tompaso Barat Kabupaten Minahasa. Zootek 36 (1): 167-173.

Montiel, F. and C. Ahuja. 2005. Body condition and sucling as factors influencing the duration of postpartum anestrus in cattle: A review. Anim Reprod. Sci 85 :1-26
Prasojo, G., I. Arifiantini, dan K. Mohamad. 2010. Korelasi Anatara lama kebuntingan, bobot lahir dan jenis kelamin pedet hasil inseminasi buatan pada Sapi Bali. Jurnal Veteriner. 11(1):41-45.

Rhodes, F. M., S. McDougall, C. R. Burke, G. A. Verkerk, and K.L Macmilan. 2003. Invited Review: Treatment of cows with an extended postpartum anestrous interval. $\mathrm{J}$. Dairy Sci. 86 (6): 1876-1884.

Saladin, R. 1993. Teknik Produksi Sapi Potong. Diktat . Departemen Pendidikan dan Kebudayaan Universitas Andalas. Padang.

Sugiyono, (2010). Metode Penelitian Kuantitatif, Kualitatif, dan R\&D. Alfabeta. Bandung.

Toelihere, M. R, 1995. Fisiologi Reproduksi Pada Ternak. Angkasa. Bandung

Wibowo, F.C.P, N. Isnaini. Dan S. Wahjuningsigh, 2014 Performans Reproduksi Sapi Peranakan Ongele dan Sapi Peranakan Limousine di Kecamatan Berbek Kabupaten Nganjuk. Skripsi. Fakultas Peternakan Brawijaya. Malang.

Winarti, E dan Supriyadi. 2010. Penampilan Reproduksi Ternak Sapi Potong Betina di Daerah Istimewa Yogyakarta. Seminar Nasional Teknologi Peternakan dan Veteriner. Balai Pengkajian Teknologi Pertanian Yogyakarta Hal :64-67. 